\title{
Bacteriological Examination of Cooked Meat and Chicken Meals
}

\author{
Fahim A Shaltout ${ }^{1 *}$, Hanan M Lamada ${ }^{2}$ and Ehsan A M Edris ${ }^{3}$ \\ ${ }^{1}$ Department Food Hygiene, Faculty of Veterinary, Egypt \\ ${ }^{2}$ Animal Health Research, Tanta University, Egypt \\ ${ }^{3}$ Tanta University Hospitals, Egypt
}

*Corresponding author: Fahim A Shaltout, Department of Food Hygiene, Faculty of Veterinary, Benha University, Egypt

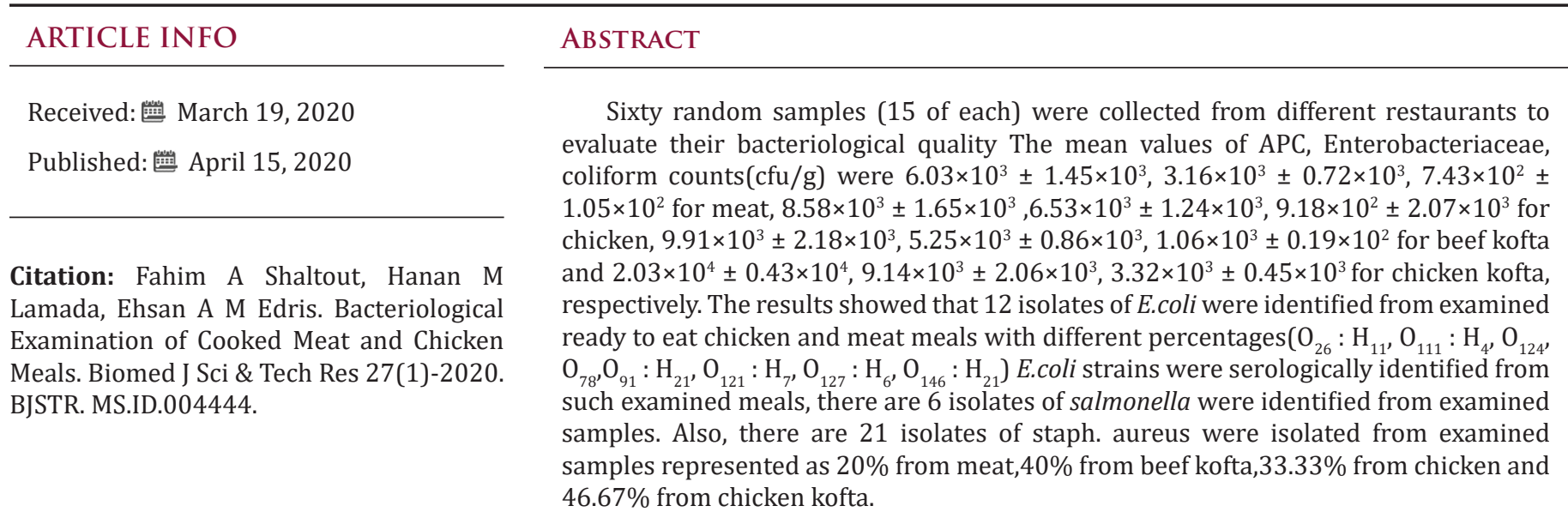

\section{Introduction}

Cooked meat and chicken meals due to their high nutritive value and agreeable taste. Meat meals have an excellent source of high-quality protein, vitamin and mineral [1,2]. Raw materials of bad microbial quality, bad personal hygiene and consumption at room temperature lead to contamination of foods with pathogenic bacteria especially Salmonellae and coliforms, causing potential risk to human [3]. Incorrect habits responsible for microbial food borne illness reported [4] and typically involve cross contamination of raw and cooked foods, poor cooking and storage at unsuitable temperature. Staphylococcal food poisoning has rapid onset and its symptoms include nausea and strong vomiting with or without diarrhoea [5]. Salmonella spp can persist on final raw products. Disease can result when these products are handled without good hygienic practices, not properly cooked and/or subjected to temperature abuse [6]. It is considered that the presence of Salmonella spp in products makes it unsafe for human consumption $[7,8]$.
E.coli is an important organism involved in food - borne disease, it is considered as a good indicator of possible fecal contamination [9]. Therefore, the present study was planned out for determination of APC, Enterobacteriaceae \& coliforms counts, isolation and identification of E.coli, salmonella and staph. aureusfor ready to eat meat and chicken meals including meat, chicken , beef kofta and chicken kofta.

\section{Materials and methods}

\section{Collection of Samples}

Sixty random samples of cooked chicken and meat meals including meat, chicken, beef kofta and chicken kofta (15 of each) were collected from different restaurants. Each sample was kept in a separate sterile plastic bag, put in an ice box then transferred to the laboratory under complete aseptic condition without any retard for the examination bacteriologically. 


\section{Preparation of Samples [10]:}

To 25 grams of the sample, $225 \mathrm{ml}$ of sterile peptone water was added thoroughly mixed sterile blender for 2.5 minutes, from which tenth fold serial dilution was prepared. The prepared samples were subjected to the following bacteriological investigations:

a. Determination of APC [10].

b. Determination of total Enterobacteriaceae count [11] using Violet Red Bile Glucose agar.

c. Determination of total coliform count [10] using Violet Red Bile agar medium.

d. Isolation and identification of Enteropathogenic E.coli [12]: it was applied by using Macconkey broth as enriched broth and EMB as plating media.

e. Isolation and Identification of salmonellae [13]

f. Isolation and identification of staph.aureus [10].

\section{Results}

The results of bacteriological examination of cooked chicken and meat meals samples revealed that APC and coliform were highest in chicken kofta followed by beef kofta then chicken then meat. While, Enterobacteriaceae was highest in chicken kofta followed by chicken then beef kofta then meat. Isolation and identification of E.coli in the examined samples revealed that the incidence of E.coli was $26.67 \%$ in chicken, $20 \%$ in both of beef kofta and 13.33 in meat,12 isolates of E.coli represented as $13.33 \%$ from meat with serotypes $\mathrm{O}_{26}: \mathrm{H}_{11}(6.67 \%)$ and $\mathrm{O}_{111}: \mathrm{H}_{4}(6.67) 20 \%$ from beef kofta with serotypes $\mathrm{O}_{26}: \mathrm{H}_{11}(13.33 \%)$ and $\mathrm{O}_{124}(6.67 \%)$. $20 \%$ from chicken with serotypes $\mathrm{O}_{78}(6.67 \%), \mathrm{O}_{127}: \mathrm{H}_{6}(6.67 \%)$ and $\mathrm{O}_{146}: \mathrm{H}_{21}(6.67 \%) .26 .67 \%$ from chicken kofta with serotypes $\mathrm{O}_{26}: \mathrm{H}_{11}(13.33 \%), \mathrm{O}_{91}: \mathrm{H}_{21}(6.67 \%)$ and $\mathrm{O}_{121}: \mathrm{H}_{7}(6.67 \%)$. Isolation and identification of salmonella in the examined samples revealed that the incidence of salmonella was equal in meat, beef kofta and chicken $(6.67 \%)$ while in chicken kofta was the highest $(20 \%)$. $6.67 \%$ from meat with serotype S. Heidelberg $6.67 \%$ from beef kofta with serotype S. Montevideo $6.67 \%$ from chicken with serotype S. Kentuckey $20 \%$ from chicken kofta with serotypes S. Anatum (6.67\%), S. Infantis(6.67\%)and S. Typhimurium(6.67\%). Isolation and identification of staphylococcus aureus revealed that there are 21 isolates of staph.aureus were isolated from examined samples represented as $20 \%$ from meat, $40 \%$ from beef kofta,33.33\% from chicken and $46.67 \%$ from chicken kofta.

\section{Discussion}

APC is very important for evaluation of sanitary condition of cooked meat meals. limits suggested for total aerobic bacterial count I in various foods range from $10^{5}$ to $10^{7}$ microbes $/ g$.(EEC,2005). It is evident from the results recorded in (Table 1) that the APC/g of the examined samples of cooked chicken and meat meals ranged from $2.1 \times 10^{3}$ to $1.7 \times 10^{4}$ with an average of $6.03 \times 10^{3} \pm 1.45 \times 10^{3} /(\mathrm{cfu} / \mathrm{g})$ for meat, $4.6 \times 10^{3}$ to $2.9 \times 10^{4}$ with an average $9.91 \times 10^{3} \pm 2.18 \times 10^{3}$ / (cfu/g) for meat kofta, , $3.5 \times 10^{3}$ to $3.9 \times 10^{4}$ with an average $8.58 \times 10^{3}$ $\pm 1.65 \times 10^{3} /$ (cfu/g) for chicken and $6.0 \times 10^{3}$ to $7.7 \times 10^{4}$ with an average $2.03 \times 10^{4} \pm 0.43 \times 10^{4}(\mathrm{cfu} / \mathrm{g})$ for chicken kofta. The current results nearly similar to the results recorded by Sobieh (2014) found that the mean value of RTE kofta was $1.83 \times 10^{4} \mathrm{cfu} / \mathrm{gm}$, while higher results was recorded by [14] who found that the mean value of APC of RTE kofta was $8.51 \times 10^{5} \mathrm{cfu} / \mathrm{g}$, also higher results was recorded by [14] found that the mean APC of RTE chicken meals was $1.9 \times 10^{4}$ $\mathrm{cfu} / \mathrm{g}$ and in RTE meat meals was $1.2 \times 10^{4} \mathrm{cfu} / \mathrm{g}$.high incidence of APC , may indicate that the cooking process was inadequate, or post cooking contamination had occurred, or the length of time and temperature control in storage or display facilities was inadequate to prevent bacterial contamination, or that a combination of these factors was involved [15].

Table 1: Analytical results of Aerobic plate counts/g (APC) in the examined samples of cooked meat and chicken meals $(n=15)$.

\begin{tabular}{|c|c|c|c|}
\hline Meals & Min & Max & Mean \pm S.E* \\
\hline \multicolumn{4}{|c|}{ Meat meals: } \\
\hline Meat meals: & $2.1 \times 10^{3}$ & $1.7 \times 10^{4}$ & $6.03 \times 10^{3} \pm 1.45 \times 10^{3}$ \\
\hline Meat meals: & $2.1 \times 10^{3}$ & $1.7 \times 10^{4}$ & $6.03 \times 10^{3} \pm 1.45 \times 10^{3}$ \\
\hline \multicolumn{4}{|c|}{ Chicken meat meals: } \\
\hline Chicken meat & $3.5 \times 10^{3}$ & $3.9 \times 10^{4}$ & $8.58 \times 10^{3} \pm 1.65 \times 10^{3}$ \\
\hline Kofta & $3.5 \times 10^{3}$ & $3.9 \times 10^{4}$ & $8.58 \times 10^{3} \pm 1.65 \times 10^{3}$ \\
\hline
\end{tabular}

Table 2: Acceptability of the examined samples of cooked meat and chicken meals based on their APC $(n=15)$.

\begin{tabular}{|c|c|c|c|c|c|}
\hline \multirow{2}{*}{ Meals } & \multirow{2}{*}{ APC /g } & \multicolumn{2}{c|}{ Accepted Samples } & \multicolumn{2}{c|}{ Unaccepted Samples } \\
\cline { 3 - 6 } & & No. & $\%$ & No. & $\%$ \\
\hline \multicolumn{5}{|c|}{ Meat meals* } \\
\hline \multirow{2}{*}{ Meat } & \multirow{2}{*}{$10^{4}$} & 13 & 86.67 & 2 & 13.33 \\
\cline { 3 - 6 } Kofta & 11 & 73.33 & 4 & 26.67 \\
\hline \multicolumn{7}{|c|}{ Chicken meat meals** } \\
\hline Chicken & \multirow{2}{*}{$10^{4}$} & 12 & 80 & 3 & 20 \\
\cline { 1 - 5 } Kofta & 9 & 60 & 6 & 40 \\
\hline
\end{tabular}

*Center for Food Safety (2014) for cooked meat meals **EOS (2005) for heat treated poultry meat.

Results given in Table 2 revealed that the Acceptability of the examined samples of cooked meat and chicken meals based on their APC was $(86.67 \%$ ) of meat samples were accepted samples but $(13.33 \%)$ of meat samples were unaccepted ,(73.33\%) of beef kofta samples were accepted but ( $26.67 \%$ )of beef kofta samples were unaccepted,(80\%) of chicken samples were accepted but( $20 \%$ ) of chicken samples were unaccepted and (60\%) of chicken kofta were accepted but (40\%) )of chicken kofta were unaccepted. Results achieved in (Table 3) showed that the mean values of total Enterobacteriaceae counts/g in the examined samples of cooked 
chicken and meat meals were $3.16 \times 10^{3} \pm 0.72 \times 10^{3} /(\mathrm{cfu} / \mathrm{g}$ ) for meat, $5.25 \times 10^{3} \pm 0.86 \times 10^{3} /(\mathrm{cfu} / \mathrm{g})$ for meat kofta, $6.53 \times 10^{3} \pm 1.24 \times 10^{3} /$ (cfu/g)for chicken and $9.14 \times 10^{3} \pm 2.06 \times 10^{3} /$ (cfu/g) for chicken kofta. the current results was nearly similar to recorded by Shaltout et al.(2015) who found that the mean values of enterobacteriacea of RTE kofta was $7.15 \times 10^{3} /(\mathrm{cfu} / \mathrm{g})$, while higher results recorded by [16] who found the mean value of enterobacteriacae of street vended kofta samples was $1.5 \times 10^{7} \mathrm{cfu} / \mathrm{g}$.

Table 3: Analytical results of Enterobacteriaceae counts/g in the examined samples of cooked meat and chicken meals $(n=15)$.

\begin{tabular}{|c|c|c|c|}
\hline Meals & Min & Max & Mean \pm S.E* \\
\hline \multicolumn{3}{|c|}{ Meat meals: } \\
\hline Meat & $2.2 \times 10^{2}$ & $8.1 \times 10^{3}$ & $3.16 \times 10^{3} \pm 0.72 \times 10^{3}$ \\
\hline Kofta & $5.7 \times 10^{2}$ & $1.5 \times 10^{4}$ & $5.25 \times 10^{3} \pm 0.86 \times 10^{3}$ \\
\hline \multicolumn{4}{|c|}{ Chicken meat meals: } \\
\hline Chicken & $4.5 \times 10^{2}$ & $1.6 \times 10^{4}$ & $6.53 \times 10^{3} \pm 1.24 \times 10^{3}$ \\
\hline Kofta & $7.8 \times 10^{2}$ & $2.8 \times 10^{4}$ & $9.14 \times 10^{3} \pm 2.06 \times 10^{3}$ \\
\hline
\end{tabular}

Table 4: Analytical results of coliform counts/g in the examined samples of cooed meat and chicken meals $(n=15)$.

\begin{tabular}{|c|c|c|c|c|c|}
\hline \multirow{8}{*}{ Meals } & +ve samples & \multirow{5}{*}{ Min } & Max & Mean \pm S.E* \\
\cline { 2 - 5 } & No. & $\%$ & & \\
\hline \multicolumn{7}{|c|}{ Chicken meat meals: } \\
\hline Meat & 7 & 46.67 & $1.0 \times 10^{2}$ & $2.3 \times 10^{3}$ & $7.43 \times 10^{2} \pm 1.05 \times 10^{2}$ \\
\hline Kofta & 8 & 53.33 & $1.0 \times 10^{2}$ & $4.9 \times 10^{3}$ & $1.06 \times 10^{3} \pm 0.19 \times 10^{2}$ \\
\hline \multicolumn{7}{|c|}{ meals } \\
\hline Chicken & 8 & 53.33 & $1.0 \times 10^{2}$ & $3.7 \times 10^{3}$ & $9.18 \times 10^{2} \pm 2.07 \times 10^{3}$ \\
\hline Kofta & 9 & 60 & $1.0 \times 10^{2}$ & $7.0 \times 10^{3}$ & $3.32 \times 10^{3} \pm 0.45 \times 10^{3}$ \\
\hline
\end{tabular}

Table 5: Incidence and serotyping of Enteropathogenic E.coli isolated from the examined samples of cooked meat meals $(n=15)$.

\begin{tabular}{|c|c|c|c|c|c|}
\hline \multirow{2}{*}{ Meat meals } & \multicolumn{2}{|c|}{ Meat } & \multicolumn{2}{c|}{ Kofta } & $\begin{array}{c}\text { Strain } \\
\text { Characteristics }\end{array}$ \\
\hline Chicken meat meals & No. & $\%$ & No. & $\%$ & \\
\hline $\mathrm{O}_{26}: \mathrm{H}_{11}$ & 1 & 6.67 & 2 & 13.33 & EHEC \\
\hline $\mathrm{O}_{11}: \mathrm{H}_{4}$ & 1 & 6.67 & - & - & EHEC \\
\hline $\mathrm{O}_{124}$ & - & - & 1 & 6.67 & EIEC \\
\hline Total & 2 & 13.33 & 3 & 20 & \\
\hline
\end{tabular}

From the results in (Table 4), it is obvious that the mean values of total coliform counts/(cfu/g) in the examined samples of cooked chicken and meat meals were $7.43 \times 10^{2} \pm 1.05 \times 10^{2} /(\mathrm{cfu} / \mathrm{g})$ for meat, $1.06 \times 10^{3} \pm 0.19 \times 10^{2} /(\mathrm{cfu} / \mathrm{g})$ for meat kofta, $9.18 \times 10^{2} \pm$ $2.07 \times 10^{3} /(\mathrm{cfu} / \mathrm{g})$ for chicken and $3.32 \times 10^{3} \pm 0.45 \times 10^{3} /(\mathrm{cfu} / \mathrm{g})$ for chicken kofta. The current results was nearly similar to the results recorded by [17] who found that the mean values of coliform was $5.17 \times 10^{2} \pm 1.2 \times 10^{2} \mathrm{cfu} / \mathrm{g}$. while higher results was recorded by [18] who found the mean value of coliform count of kofta sandwiches was $1.8 \times 10^{5} /(\mathrm{cfu} / \mathrm{g})$. From the results in Tables 5 and 6 showed that there are 12 isolates of E.coli represented as $13.33 \%$ from meat with serotypes $\mathrm{O}_{26}: \mathrm{H}_{11}(6.67 \%)$ and $\mathrm{O}_{111}: \mathrm{H}_{4}(6.67) 20 \%$ from beef kofta with serotypes $\mathrm{O}_{26}: \mathrm{H}_{11}(13.33 \%)$ and $\mathrm{O}_{124}(6.67 \%) .20 \%$ from chicken with serotypes $078(6.67 \%), \mathrm{O}_{127}: \mathrm{H}_{6}(6.67 \%)$ and $\mathrm{O}_{146}$ : $\mathrm{H}_{21}(6.67 \%) .26 .67 \%$ from chicken kofta with serotypes $\mathrm{O}_{26}$ : $\mathrm{H}_{11}(13.33 \%), \mathrm{O}_{91}: \mathrm{H}_{21}(6.67 \%)$ and $\mathrm{O}_{121}: \mathrm{H}_{7}(6.67 \%)$.

Table 6: Incidence and serotyping of EnteropathogenicE.coli isolated from the examined samples of cooked chicken meals $(n=15)$

\begin{tabular}{|c|c|c|c|c|c|}
\hline \multirow{2}{*}{ Chicken meals } & \multicolumn{2}{|c|}{ Chicken } & \multicolumn{2}{|c|}{ Kofta } & $\begin{array}{c}\text { Strain } \\
\text { Characteristics }\end{array}$ \\
\hline No. & $\%$ & No. & $\%$ & $\%$ & \\
\hline $\mathrm{O}_{26}: \mathrm{H}_{11}$ & - & - & 2 & 13.33 & EHEC \\
\hline $\mathrm{O}_{78}$ & 1 & 6.67 & - & - & EPEC \\
\hline $\mathrm{O}_{91}: \mathrm{H}_{21}$ & - & - & 1 & 6.67 & EHEC \\
\hline $\mathrm{O}_{121}: \mathrm{H}_{7}$ & - & - & 1 & 6.67 & EHEC \\
\hline $\mathrm{O}_{127}: \mathrm{H}_{6}$ & 1 & 6.67 & - & - & ETEC \\
\hline $\mathrm{O}_{146}: \mathrm{H}_{21}$ & 1 & 6.67 & - & - & EPEC \\
\hline Total & 3 & 20 & 4 & 26.67 & \\
\hline
\end{tabular}

From Tables 7 and 8 showed the incidence and serotyping of salmonella isolated from cooked meat and chicken meals is $6.67 \%$ from meat identified serologically as S. Heidelberg $\mathrm{O}_{4,5,12}: \mathrm{H}_{\mathrm{r}: 1}, 26.67 \%$ from beef kofta identified serologically as S. Montevideo $\mathrm{O}_{6,7,14}: \mathrm{H}_{\mathrm{g}, \mathrm{m}, \mathrm{s}}: 1,7,26.67 \%$ from chicken identified serologically as S. Kentuckey $\mathrm{O}_{8,20}: \mathrm{H}_{\mathrm{i}: \mathrm{Z}} 20 \%$ from chicken kofta identified serologically as S. Anatum01,9,12:Hg,m:1,7(6.67\%), S. Infantis $\mathrm{O}_{6,7,14}: \mathrm{H}_{\mathrm{r}: 1,5}(6.67 \%)$ and $\mathrm{S}$. TyphimuriumO $\mathrm{O}_{1,4,5,12}: \mathrm{H}_{\mathrm{i}: 1,2}(6.67 \%)$. Salmonella microorganisms were previously isolated from cooked meat meals by $[19,20]$. Also, salmonella failed to be isolated from cooked meat meals by [21]. The symptoms the symptoms of salmonellosis include diarrhoea, nausea, vomiting, fever and abdominal cramps [22]. The results in Tables 9 and 10 reported that staph .aureus was isolated from $20 \%$ of meat, $40 \%$ of meat kofta,33.33\%of chicken and $46.67 \%$ of chicken kofta .such organism was isolated previously from ready to eat meat meals by $[19,21]$ who isolated staph aureus from cooked samples the presence of staph aureus in RTE meat meals may be due to their contamination from food handlers, bad cleaned equipment's or post processing contamination [23-25].

Table 7: Incidence and serotyping of Salmonellae isolated from the examined samples of cooked meat meals $(n=15)$.

\begin{tabular}{|c|c|c|c|c|c|c|c|}
\hline \multirow{2}{*}{$\begin{array}{c}\text { Salmonella } \\
\text { serotypes }\end{array}$} & \multicolumn{2}{|c|}{ Meat } & \multicolumn{2}{c|}{ Kofta } & \multirow{2}{*}{ Group } & \multicolumn{2}{c|}{$\begin{array}{c}\text { Antigenic } \\
\text { Structure }\end{array}$} \\
\cline { 2 - 5 } & No. & No. & No. & $\%$ & & 0 & H \\
\hline S. Heidelberg & 1 & 6.67 & - & - & B & $4,5,12$ & r: 1,2 \\
\hline S. Montevideo & - & - & 1 & 6.67 & C1 & $6,7,14$ & $\begin{array}{c}\text { g,m,s: } \\
1,2,7\end{array}$ \\
\hline Total & 1 & 6.67 & 1 & 6.67 & & & \\
\hline
\end{tabular}


Table 8: Incidence and serotyping of Salmonellae isolated from the examined samples of cooked chicken meals $(n=15)$.

\begin{tabular}{|c|c|c|c|c|c|c|c|}
\hline \multirow{2}{*}{$\begin{array}{c}\text { Salmonella } \\
\text { serotypes }\end{array}$} & \multicolumn{2}{|c|}{ Chicken } & \multicolumn{2}{|c|}{ Kofta } & \multirow{2}{*}{ Group } & \multicolumn{2}{c|}{$\begin{array}{c}\text { Antigenic } \\
\text { Structure }\end{array}$} \\
\cline { 2 - 5 } & No. & No. & No. & $\%$ & & 0 & H \\
\hline S. Anatum & - & - & 1 & 6.67 & D1 & $1,9,12$ & $\begin{array}{c}\text { g,m : } \\
1,7\end{array}$ \\
\hline S. Kentuckey & 1 & 6.67 & - & - & C3 & 8,20 & i : Z6 \\
\hline S. Infantis & - & - & 1 & 6.67 & C1 & $6,7,14$ & $\mathrm{r}: 1,5$ \\
\hline $\begin{array}{c}\text { S. } \\
\text { Typhimurium }\end{array}$ & - & - & 1 & 6.67 & B & $1,4,5,12$ & $\mathrm{i}: 1,2$ \\
\hline Total & 1 & 6.67 & 3 & 20 & & & \\
\hline
\end{tabular}

Table 9: Incidence of Staphylococcus aureus isolated from the examined samples of cooked meat meals $(n=15)$.

\begin{tabular}{|c|c|c|}
\hline \multirow{2}{*}{ Meat meals } & \multicolumn{2}{|c|}{ Positive samples } \\
\cline { 2 - 3 } & No. & \% \\
\hline Meat & 3 & 20 \\
\hline Kofta & 6 & 40 \\
\hline Total (30) & 9 & 30 \\
\hline
\end{tabular}

Table 10: Incidence of Staphylococcus aureus isolated from the examined samples of cooked chicken meals $(n=15)$.

\begin{tabular}{|c|c|c|}
\hline \multirow{2}{*}{ Chicken meals } & \multicolumn{2}{|c|}{ Positive samples } \\
\cline { 2 - 3 } & No. & \% \\
\hline Chicken & 5 & 33.33 \\
\hline Kofta & 7 & 46.67 \\
\hline Total (30) & 12 & 40 \\
\hline
\end{tabular}

\section{References}

1. (1984) World Health Organization 'WHO' 1984. The role of food safety in health development. Report of Joint FAO/WHO Expert Committee on Food Safety, Geneva.

2. Mosupy FM, Arntzen L, Von Holy A (1998) Microbiological survey of street-vended food in the Johannesburg metropolitan area of South Africa. Food Sci 63(7): 842-846.

3. Kiipliilii B, Sarimehmetoglu B, Oral N (2003) The microbiological quality of Cig kofta sold in Ankara. Turk Veterinerlikve Hayvancilik Dergisi 27(2): 325-329.

4. Egan MB, Raats MM, Grubb SM, Eves A, Lumbers ML, et al. (2007) A review of food safety and food hygiene training studies in the commercial sector food control 18: 1180-1190.

5. Argudin MA, Mendoza MC, Rodico MR (2010) Food poisoning and staphylococcus aureus enterotoxins. Toxins 2(7): 1751-1773.

6. Zhang I, Davis MA, Conner DE (2001) Poultry-borne pathogens: plant considerations. Poultry Meat processing chap 9 ISBN 0 -8493-0120 -3, CRC Press LLC, New York, USA.

7. Agunos A (2007) Effect of dietary beta 1-4 mannobiose in the prevention of Salmonella enteritidis infection in broilers. British Poultry Science 48(3): 331-341.
8. Muth MK (2009) Analysis of Salmonella control performance in US. young chicken slaughter and pork slaughter establishments. J of Food Prot 72(1): 6-13.

9. Synge BA (2000) Verocytotoxin Producing E coli a veterinary review. J appl Microbiol Symposium Suppl 88: 31S-37S.

10. ICMSF (1996) International commission of Microbiological Specification for Foods Microorganisms in Food. I-Their Significance and methods of enumeration. $3^{\text {rd }}$ Edn Univ of Toronto, Canada.

11. GorkEP(1976)UberdieUrsachenvon Qualitatstmangelnbeitiefgeforenen Fertiggerichten auf fleischbasis in der Fluggastverpflegung Vet Med Diss tech Univ Berlin, Germany.

12. ISO (2001) International Organization of Standardization. Microbiology of food, animal feeding stuffs. Horizontal method for the enumeration of $\beta$ - glucuronidas- Positive E-Coli. Part 2: Colony- Count technique at $44^{\circ} \mathrm{C}$ using 5 bromo 4 chloro-3- indolyl $\beta$-Dglucuronide 16649-16652.

13. ISO (2002) International organization of standardization. No.6579. Microbiogy of food and animal feeding stuffs. Horizontal Methods for detection of Salmonellae species.

14. Shaltout FA, Mohamed AH, El Shater, Wafaa Mohamed Abd El Aziz (2015) Bacteriological assessment of Street Vended Meat Products sandwiches in kalyobia Governorate. J Benha vet Med 28(2): 58-66.

15. Khater Dalia F, Heikal GE, Shehata AA, El Hofy FI (2013) The Microbiological Assessment of Ready-To-Eat-Food (Liver and Kofta Sandwiches) In Tanta City, Egypt. Benha Vet Med J 25(2): 187-197.

16. Shaltout FA, Amani MS, Mahmoud AH, AbdElraheem KA (2013) Bacterial aspect of cooked meat and edible offal at street vendors level. J Benha vet Med 24(1): 320-328.

17. Saad MS, Hemat MI, Enas AMA (2011) Microbial and chemical evaluation of fast foods. J Benha vet.

18. Hussein MI (1996) Microbial evaluation of some meat meals of Assiut restaurants. M VSc Thesis Fac of Vet Medicine Assiut University. International commission of Med SE (1): 44-51.

19. Soliman MR, Abd El Monem KM, Saad SM (2002) Microbiological quality of ready-to-eat meat product and fishes in Urban and rural areas. J Egypt Vet Med Assoc 62(6): 39-51.

20. Richardson IR, Stevens AM (2003) Microbiological examination of ready-to-eat stuffing from retail premises in the north-east of England. The "Get Staffed" survey. J Appl Microbiol 94(4): 733-737.

21. Kirralla GA (2007) Sanitary status of meat meals of students of Tanta University. MVSc Thesis meat hygiene Fac Vet Med kafr El Shickh University.

22. Cui S (2004) Detection and characterization of Escherichia coli 0 157: H7 and Salmonella in food. Ph D Thesis Fac Graduate School, Univ Maryland College Park. USA.

23. Duff G, Kilbride B, Sherdian JJ, Blair IS, McDowell DA (2000) A membrane-immune-fluorescet validity staining technique for the detection of Salmonella species from fresh and processed meat samples. J appl Microbiol 1 89(4): 587-594.

24. EEC (2005) Commission regulation (EC) No.2073/2005 on microbiological criteria for foodstuffs. Council of the European Communities (EEC) Off J Eur Commu 338: 422.

25. Shaltout FA, Zakaria IM, Jehan Eltanani, Asmaa S Elmelegy (2015) Microbiological status of meat and chicken received to University student hostel. J Benha vet Med 29(2): 187-192. 
ISSN: 2574-1241

DOI: $10.26717 /$ BJSTR.2020.27.004444

Fahim A Shaltout. Biomed J Sci \& Tech Res

(C) (P) This work is licensed under Creative

Submission Link: https://biomedres.us/submit-manuscript.php

\begin{tabular}{ll} 
BIOMEDICAL & Assets of Publishing with us \\
RESEARCHES & - Global archiving of articles \\
& - Immediate, unrestricted online access \\
\hline
\end{tabular}

